Sebastian Gałecki

\title{
O możliwości istnienia filozofii chrześcijańskiej
}

DOI: http://dx.doi.org/10.12775/RF.2016.028

\section{Wprowadzenie}

W (jedynej dotychczas) polskiej encyklopedii filozofii znaleźć możemy hasło Chrześcijańska filozofia, która tak jest przez autorów definiowana: „typ filozofii ukształtowanej w kręgu doktrynalnego oddziaływania chrześcijaństwa lub uwzględniający w jakiś sposób chrześcijańskie objawienie”, bezpośrednio po tym dodając, iż „pojęcie «chrześcijańska filozofia» jest przedmiotem kontrowersji ze względu na to, że filozofia, jako wiedza czysto racjonalna, jest niezależna od religijnego objawienia (niektórych jej form historycznych nie można jednak zrozumieć bez uwzględnienia wpływu wiary chrześcijańskiej)"47. Bardzo ciekawe jest to stwierdzenie: podając w pierwszym zdaniu zwięzłą definicję filozofii chrześcijańskiej (a właściwie dwie alternatywne definicje), w następnym autorzy czują się w obowiązku podkreślić jej kontrowersyjność. Jej, czyli nie tylko zaproponowanej definicji, ale również - a może przede wszystkim - kontrowersyjność samego pojęcia „filozofia chrześcijańska”. Problematyczność tej idei przypomina bowiem błąd logiczny contradictio in adiecto, wewnętrznej sprzeczności samego pojęcia.

Niniejszy artykuł chce podjąć jeszcze raz ten problem, odpowiadając na pytanie: czy możliwa jest filozofia chrześcijańska (w kolejnym artykule będę chciał odpowiedzieć na związane z tym kolejne pytanie: jak jest możliwa?). Piszę „jeszcze raz”, ponieważ dyskusja na temat sensow-

47 Zofia J. Zdybicka, Edward I. Zieliński, Chrześcijańska filozofia, w: Powszechna Encyklopedia Filozofii, A. Maryniarczyk (red.), t. II, Polskie Towarzystwo Tomasza z Akwinu, Lublin 2001, s. 167. 
ności tej idei trwa od blisko dwudziestu wieków, swą najdojrzalszą - jak dotąd - postać przyjmując $\mathrm{w}$ dwudziestowiecznym sporze toczonym w środowisku frankofońskim, pomiędzy tak znaczącymi myślicielami, jak Émile Bréhier, Étienne Gilson, Jacques Maritain, Maurice Blondel, Maurice Nédoncelle i innymi ${ }^{48}$. W dużo skromniejszej formie ta słynna debata znalazła odzwierciedlenie również w naszym kraju. Pozwolę sobie przywołać tylko dwa przykłady próby systematyzacji, zaproponowane przez filozofów związanych z chrześcijańskimi ośrodkami naukowymi.

Mieczysław Gogacz, związany z (nomen omen) Wydziałem Filozofii Chrześcijańskiej ATK, w $1981^{49}$ roku pisał o czterech sposobach rozumienia pojęcia "filozofia chrześcijańska" i czterech jej sensach. Pozostawmy chwilowo na boku drugą listę i przyjrzyjmy się pierwszej, poświęconej analizie socjologicznej. W ówczesnej Polsce, zdaniem Gogacza, omawiany termin był rozumiany na cztery sposoby, w zależności od tego, kto go używa. Marksiści używali tego określenia dla opisania szeroko rozumianej kultury chrześcijańskiej, perspektywa bardziej potoczna (podzielana przez „niemarksistów, niefilozofów i nieteologów”) utożsamia ją $\mathrm{z}$ poglądami filozoficznymi nie będącymi w kolizji z prawdami wiary, teologowie opisują nim te problemy, którymi przekazuje treści wiary religijnej, zaś filozofowie posługują się pojęciem „filozofia chrześcijańska" w zależności od swojej proweniencji - na co najmniej czternaście dalszych wariantów.

Wydaje się, że właśnie do tego ostatniego, filozoficznego sposobu używania dyskutowanego terminu odnosił się nieodżałowany myśliciel z Katolickiego Uniwersytetu Lubelskiego, Wojciech Chudy ${ }^{50}$. Jego przegląd zawiera trzy podstawowe stanowiska odnośnie do możliwości istnienia filozofii chrześcijańskiej, z których ostatnie dzieli się na kilka dalszych koncepcji. Pierwsze dwa mają charakter skrajny: stanowisko radykalnie dualistyczne - nie istnieje filozofia chrześcijańska, można o niej mówić jedynie w sensie historycznym (Mercier, Bréhier, Russel) oraz stanowisko radykalnie negujące autonomię filozofii - filozofia tylko jako ancilla theologiae, podporządkowanie rozumu wierze (Justyn Męczennik, Kalwin, Erazm, do pewnego stopnia Augustyn z Hippony).

Ostatnie stanowisko afirmuje filozofię chrześcijańska, choć w różnym stopniu. Jego wyznawcy mogą postrzegać wpływ wiary na filozofię

48 Zob. Kazimierz Szałata, Filozofia chrześcijańska. Na marginesie wielkiej debaty od encykliki "Aetarni Patris" do "Fides et ratio", Fundacja Polska Raoula Follereau, Warszawa 200, s. 41-101; Wojciech Chudy, Filozofia chrześcijańska - rozum i wiara, „Ethos” 3-4 (2007) 79-80, s. 50-54; Zofia J. Zdybicka, Edward I. Zieliński, Chrześcijańska filozofia, art. cyt., s. $178-183$.

${ }_{49}$ Zob. Mieczysław Gogacz, Czym jest filozofia chrześcijańska, "Za i Przeciw” 14 (5 kwietnia) 1981, s. 6.

50 Zob. Wojciech Chudy, Filozofia chrześcijańska - rozum i wiara, art. cyt., s. 50-54. 
jedynie na sposób zewnętrzny (głównie neotomiści), inni uznają ściślejszy wpływ wiary na filozofię, quasi-wewnętrzny, podkreślający nie tylko negatywny, ale również pozytywny wpływ wyznawanej wiary na filozofię (Gilson, Maritain). Jeszcze inni deklarują podmiotową otwartość filozofii na wiarę religijną - w punkcie wyjścia autonomiczna i czysto racjonalna filozofia staje się otwarta (a nawet zależna) na wpływ religii chrześcijańskiej w punkcie dojścia (Blondel, Nédoncelle, Tresmontant:) albo wręcz dopuszczają w filozofii elementy irracjonalne, mówiąc o „paradoksie wiary" czy "zgodzie na Tajemnicę" (Marcel, Ricœur). Każde z tych stanowisk $\mathrm{w}$ odmienny sposób akceptuje istnienie filozofii chrześcijańskiej, jednocześnie polemizując z dwiema wcześniejszymi, które wychodząc bądź z przesłanek metodologicznych, bądź teologicznych odrzucają możliwość jej istnienia.

Najlepiej ten wielowiekowy dylemat opisał Étienne Gilson w swoim słynnym Duchu filozofii średniowiecznej. Pozwolę sobie przytoczyć nieco dłuższy fragment:

Historykowi filozofii średniowiecznej żadne chyba określenie nie nasuwa się tak samorzutnie jak termin «filozofia chrześcijańska». Zdawałoby się, iż trudno o nazwę budzącą mniej zastrzeżeń, przeto nic dziwnego, że bywa ona tak często używana. A jednak przy bliższym rozpatrzeniu okazuje się, że niewiele jest określeń tak mglistych, tak trudnych do ścisłego zdefiniowania. Pytanie bowiem nie polega na tym, czy historykowi myśli średniowiecznej wolno systemy filozoficzne, wypracowane przez chrześcijan, rozważać w oderwaniu od tych, których twórcami byli żydzi lub muzułmanie. Postawiony w tej formie problem ma charakter czysto historyczny i może być rozwiązany bez trudu. [...] Nie tu tkwi istotny problem. Idzie bowiem o zagadnienie natury filozoficznej, o wiele bardziej ważkie. Sprowadzone do swego najprostszego sformułowania, zawiera się ono w pytaniu, czy samo pojęcie filozofii chrześcijańs k i e j ma jakikolwiek sens, a zatem czy odpowiada jakiejś rzeczywistości. Rzecz jasna, nie idzie również o stwierdzenie, czy istnieli filozofowie-chrześcijanie, ale czy mogą istnieć filozofowie chrześcijańscy ${ }^{51}$.

Gilson wyraźnie odróżnia problem historyczny od problemu radykalnie filozoficznego: czy pojęcie filozofii chrześcijańskiej ma sens? czy mogą istnieć filozofowie chrześcijańscy?

Spróbujmy przyjrzeć się kilku (przede wszystkim polskim) współczesnym przedstawicielom trzech stanowisk w sprawie sensowności posługiwania się pojęciem „filozofia chrześcijańska” oraz możliwości istnienia takiej filozofii. Te stanowiska to: radykalne odrzucenie takiej możliwości, forma pośrednia, akceptująca istnienie takiej filozofii, ale je-

51 Étienne Gilson, Duch filozofii średniowiecznej, tłum. J. Rybałt, PAX, Warszawa 1958, s. 9. 
dynie w perspektywie historycznej a nie filozoficznej, i wreszcie pogląd akceptujący istnienie filozofii chrześcijańskiej oraz podający jej kryteria. Rozpocznijmy od pierwszego z nich.

\section{"Drewniane żelazo"}

Powyższy podtytuł został zaczerpnięty ze słynnego określenia, którego autorem był Martin Heidegger. Słynny niemiecki myśliciel wypowiedział je dwukrotnie w czasie wykładów uniwersyteckich. W 1927 roku w Tübingen powiedział: „Nie istnieje zatem nic takiego, jak filozofia chrześcijańska - to po prostu «drewniane żelazo»" 52 . Powtórzył tę samą myśl w 1935 roku we Fryburgu: „«Filozofia chrześcijańska» jest drewnianym żelazem i nieporozumieniem" ${ }^{53}$. Nietrudno zrozumieć, dlaczego Heidegger tak ostro odrzucał pojęcie filozofii chrześcijańskiej: wyraźnie interpretuje to pojęcie jako contradictio in adiecto. Filozofia to żelazo - wszyscy wiemy, jakie cechy posiada żelazo; podczas gdy chrześcijaństwo - to drewno. Nie da się tego ze sobą pogodzić, bo albo będziemy mieli do czynienia z prawdziwym żelazem, jedynie pomalowanym tak, że przypomina drewniany miecz, albo też będzie to drewno, które wyłącznie z powodu jakichś okoliczności (np. ciemności) będzie wzięte za żelazo. Jakiekolwiek powiązanie tych dwóch elementów (rzeczownik „filozofia” + przymiotnik „,chrześcijańska”) jest wynikiem wyłącznie błędu poznawczego lub (według słów Heideggera) „nieporozumieniem”. Filozof uwzględniający w swej filozofii wyznawaną wiarę chrześcijańską przestaje być filozofem.

Do podobnie radykalnego wniosku - choć z całkowicie odmiennych powodów - doszedł Tertulian, których w swym słynnym apelu wołał: „Cóż jednak mają wspólnego Ateny z Jerozolimą? Kościół z Akademią? Heretycy z chrześcijanami? Nasza nauka zrodziła się w portyku Salomona, który twierdził, że Boga należy szukać w prostocie serca. Niech o tym pamiętają ci, którzy głoszą jakieś stoickie, platońskie czy dialektyczne chrześcijaństwo. Po Chrystusie Jezusie nie potrzebujemy już żadnych badań, a po Jego Ewangelii żadnych dociekań!" ${ }^{54}$. Zdaniem starożytnego teologa filozofia chrześcijańska nie z powodów metodologicznych nie istnieje, lecz pragmatycznych. Filozofia chrześcijańska jest czymś absurdalnym nie dlatego, że przymiotnik "chrześcijańska”

52 Martin Heidegger, Fenomenologia i teologia, tłum. J. Tischner, "Znak” 295-296 (1979), s. 134.

53 Martin Heidegger, Wrowadzenie do metafizyki, tłum. R. Marszałek, Wydawnictwo KR, Warszawa 2000, s. 13.

54 Tertulian, Preskrypcja przeciw heretykom, tłum. E. Stanula, w: idem, Wybór pism, ATK, Warszawa 1970, s. 47. 
neguje rzeczownik "filozofia”, lecz vice versa: to filozoficzność anihiluje chrześcijaństwo! „Boga należy szukać w prostocie serca”, bo to jest jedyna prawdziwa i pewna wiedza. Chrześcijanin uprawiający filozofię przestaje być chrześcijaninem.

Oddajmy głos jeszcze jednej opinii w ramach stanowiska uznającego filozofię chrześcijańską za sprzeczność. Krakowski filozof Michał Heller, jeden z najwybitniejszych współczesnych kosmologów, a jednocześnie ksiądz katolicki, sceptycznie odnosi się do pojęcia „filozof chrześcijański", proponując zastąpienie tego terminu określeniem „filozof-chrześcijanin". Jego zdaniem, w ten sposób unikniemy kontrowersji związanych z tradycyjnym, omawianym terminem. „A więc przede wszystkim, choć nie ma dziś ani możliwości, ani potrzeby, tworzenia od nowa czegoś, co miałoby się nazywać filozofią chrześcijańską to jednak są filozofowie (czy ogólniej myśliciele) chrześcijańscy, lub może lepiej filozofowie-chrześcijanie, czyli tacy głęboko wierzący myśliciele, którzy starają się w życiu wcielać chrześcijańskie ideały" - mamy zatem definicję nie filozofii chrześcijańskiej, lecz filozofa-chrześcijania. I Heller kontynuuje: „Ponieważ uprawianie filozofii jest także «sposobem życia», obowiązek urzeczywistniania chrześcijańskiego ideału rozciąga się więc również i na tę dziedzinę. A urzeczywistniać w niej chrześcijański ideał znaczy po prostu być dobrym filozofem, czyli fachowym, krytycznym, obiektywnym i dążącym do poznania prawdy myślicielem. W ostatnim sformułowaniu nie należy dopatrywać się próby narzucania jakichś epistemologicznych rozwiązań, lecz tylko wyrażenie pewnej moralnej postawy"55. Nie istnieje zatem filozofia chrześcijańska jako taka, a co najwyżej istnieją filozofowie, którzy uważają się za chrześcijan. Natomiast realizowanie takiego ideału "filozofa-chrześcijanina" nie odbiega niczym od ideału filozofa "bezprzymiotnikowego": tu i tu chodzi o to, by być rzetelnych, krytycznym i bezstronnym poszukiwaczem prawdy.

Przedstawicieli tego najbardziej krytycznego wobec idei filozofii chrześcijańskiej nurtu można wymienić więcej. Te trzy powyższe jednak wystarczająco dobrze pokazują zarówno stanowczość tej perspektywy, jak również pluralizm jej uzasadnień: metodologiczne, religijne, aksjologiczne. Obok nich znaleźć możemy także stanowisko bardziej umiarkowane, wyraźnie odróżniające wymiar historyczny od wymiaru merytorycznego (resp. opisowy od normatywnego), odmiennie je oceniając: zgadzając się co do możliwości badania nurtu filozofii chrześcijańskiej w perspektywie historycznej, ale negując merytoryczną i metodologiczną możliwość uprawiania filozofii chrześcijańskiej.

55 Michał Heller, Sens życia i sens wszechświata. Studia z teologii współczesnej, Biblos, Tarnów 2002, s. 57. 


\section{Wyłącznie fakt historyczny}

Przedstawicielem takiej optyki jest wspomniany już Mieczysław Gogacz. Wcześniej omówiliśmy pierwszą listę (sposobów rozumienia naszego terminu), teraz przyjrzyjmy się drugiej liście, wymieniającej cztery sensy pojęcia "filozofia chrześcijańska”. Gogacz rozpoczyna od jednoznacznej wypowiedzi: „W sensie metodologicznym nie ma filozofii chrześcijańskiej, tak jak nie ma chrześcijańskiej matematyki, czy chrześcijańskiego samochodu. Jest dobry lub zły samochód. Jest po prostu filozofia prawdziwa lub zawierająca błędy"56. Możemy poprawnie mówić o filozofii chrześcijańskiej - zdaniem warszawskiego myśliciela - wyłącznie $\mathrm{w}$ trzech innych sensach: $\mathrm{w}$ sensie historycznym (problemy filozoficzne zgłoszone i badane przez chrześcijan), w sensie antropologicznym (zagadnienia filozoficzne interesujące szczególnie chrześcijan, np. kwestia duszy) oraz w sensie światopoglądowym (,połączenie w jeden obszar metodologiczny twierdzeń filozoficznych i religijnych"). Zatem Gogacz bardzo ściśle rozróżnia charakter normatywny (nie istnieje filozofia chrześcijańska metodologicznie odrębna od filozofii niechrześcijańskiej) od potocznego, bardziej opisowego wymiaru - tutaj możemy posługiwać się tym pojęciem w znaczeniu historycznym, antropologicznym czy światopoglądowym, mając jednocześnie świadomość ułomności i nieprecyzyjności tego terminu.

Dokładnie takie samo zdanie w tej kwestii wyrażał inny nestor polskiej historii filozofii, Stefan Swieżawski: „Ściśle rzecz biorąc, nie ma filozofii chrześcijańskiej, a to dlatego, że filozofia jest sprawą pozakonfesyjną i przedkonfesyjną. Tu nie ma ani wierzącego, ani niewierzącego, ani chrześcijanina, ani muzułmanina - jest człowiek, który filozofuje. Faktem historycznym jest natomiast filozofia uprawiana przez chrześcijan; wtedy refleksja filozoficzna staje się filozofią chrześcijańską. Jest to jednak innego rodzaju «chrześcijańskość». Jeśli filozofia ma być filozofia, to nie może być w niej żadnych przesłanek, żadnych założeń, które byłyby prawdami wiary" ${ }^{\prime 57}$. Wyraźnie dostrzegamy w jego wypowiedzi rozróżnienie pomiędzy wymiarem filozoficznym, "ściśle rzecz biorąc" a wymiarem historycznym, "faktycznym”.

Tego samego sformułowania - "fakt historyczny” - używał mistrz Swieżawskiego, Étienne Gilson: „Jest faktem historycznym, że istniały systemy filozoficzne, które charakter swój zawdzięczają wierze chrześcijańskiej. Wszystkie one razem wzięte tworzą jasno zarysowaną grupę, różniącą się wyraźnie od innych grup systemów filozoficznych, np.

56 Mieczysław Gogacz, Czym jest filozofia chrześcijańska, art. cyt., s. 6.

57 Stefan Swieżawski, Święty Tomasz na nowo odczytany. Wykłady w Laskach, Znak, Kraków 1983, s. 43. 
od filozofii greckiej, łacińskiej, chińskiej albo muzułmańskiej. Wprawdzie wewnątrz naszej grupy występują często znaczne różnice, a nawet sprzeczności, ale jej podstawowa jedność zostaje zachowana. Ta grupa albo klasa, obejmująca systemy filozoficzne od czasów apostolskich aż do naszych dni, nazywana jest «filozofią chrześcijańską». Nie jest naszym celem systematyczne uzasadnianie pojęcia filozofii chrześcijańskiej, bo rozumiemy je tylko $\mathrm{w}$ sensie historycznym" ${ }^{\prime 58}$. Uznanie niemożności „systematycznego uzasadniania pojęcia filozofii chrześcijańskiej” nie neguje - zdaniem Böhnera i Gilsona - badań historycznych prowadzonych nad dziejami pewnej myśli, która przyjęła (z różnych powodów) dla siebie miano: filozofia chrześcijańska.

Mniej jednoznacznie swoją opinię wyrażają autorzy Filozofii XX wieku, podkreślając co prawda, iż filozofia historyczna jest „faktem historycznym”, pisząc jednocześnie o kontynuowaniu jej tradycji: „Istota «filozofii chrześcijańskiej» i możliwość uprawiania jej z pewnością budzą i nadal będą budzić kontrowersje. Ta filozofia jest faktem historycznym nie tylko z zamierzchłej przeszłości, ale i z dziejów najnowszych. Jej bogate dziedzictwo nie ma końca. Musi ona, kontynuując swą tradycję, zawsze dostosowywać się do ducha czasu, aby zmierzyć się z problemami danej epoki, szukać dla nich rozwiązań i je znajdować" 59 . Trudno mi sobie wyobrazić możliwość pogodzenia zamknięcia idei filozofii chrześcijańskiej w szufladzie pt. „historia filozofii” z jednoczesnym wyznaczaniem jej jakichś bieżących celów i zadań. Niemniej, ta opinia pokazuje wewnętrzny pluralizm także wewnątrz tego pośredniego stanowiska - pomiędzy zanegowaniem istnienia filozofii chrześcijańskiej a jej afirmacją.

Ten dwugłos w sprawie nie-istnienia (merytorycznej) filozofii chrześcijańskiej dobrze podsumował wspomniany już Wojciech Chudy stwierdzając, iż „należy odróżnić filozofię chrześcijańską w znaczeniu h i s t o r y c z n y m, a także filozofię rozumianą jako całościowy i zamknięty syste m od (pierwszorzędnego) merytoryczneg o pojęcia filozofii chrześcijańskiej"60. Nie poprzestaje jednak na tym, wskazując definicję takiej prawdziwej, „,merytorycznej” filozofii chrześcijańskiej („filozofowanie w ostatecznej perspektywie wiary chrześcijańskiej lub filozofię uprawianą w postawie chrześcijańskiej") oraz wymieniając jej trzy główne cechy (maksymalizm zadań, wieczystość i ponadkulturowość głównych tez oraz niesprzeczność z prawdami

58 Philotheus Böhner, Étienne Gilson, Historia filozofii chrześcijańskiej: od Justyna do Mikołaja Kuzańczyka, tłum. Stanisław Stomma, PAX, Warszawa 1962, s. 9.

59 E. Coreth, P. Ehlen, G. Haeffner, F. Ricken, Filozofia XX wieku, tłum. M.L. Kalinowski, Antyk, Kęty 2004, s. 98.

${ }^{60}$ Wojciech Chudy, Filozofia chrześcijańska - rozum i wiara, art. cyt., s. 59. 
wiary) ${ }^{61}$. Pójdźmy zatem tę samą drogą i opiszmy krótko współczesnych przedstawicieli trzeciego stanowiska uznającego nie tylko istnienie filozofii chrześcijańskiej (wbrew pierwszemu z omówionych w niniejszym artykule poglądów), ale także sensowność mówienia o niej w perspektywie metafilozoficznej, a nie tylko historycznej (wbrew stanowisku drugiemu).

\section{Afirmacja filozofii chrześcijańskiej}

Jak już zostało powiedziane, spór o istnienie specyficznej, unikalnej filozofii chrześcijańskiej (odrębnej nie tylko od innych nurtów filozoficznych, ale także od teologii), trwa niemal od dwóch tysięcy lat. Bez większego ryzyka można chyba powiedzieć, że $\mathrm{w}$ historii znajdziemy równie wielu przeciwników, jak i zwolenników możliwości istnienia takiej filozofii. Ponieważ niniejszy tekst koncentruje się przede wszystkim na myślicielach współczesnych, więc również w przypadku tego trzeciego poglądu - afirmującego istnienie filozofii i sensowność posługiwania się tym pojęciem nie tylko $\mathrm{w}$ wymiarze historycznym, ale także merytorycznym - oddamy głos przede wszystkim dwudziestowiecznym myślicielom, a ze względu na łamy, na których artykuł się ukazuje: przede wszystkim Polakom.

Rozpocznijmy jednak od wyjątku, "rodzynka” na tej liście, czyli od Francuza, bez którego trudno sobie wyobrazić współczesny tomizm polski. Étienne Gilson, bo o nim mowa, w latach trzydziestych ubiegłego wieku wygłosił cykl wykładów poświęconych filozofii chrześcijańskiej i średniowiecznej. Ukazały się one drukiem w dwóch wersjach: w 1942 roku najbardziej znane, autorskie wydanie Gilsona (w polskim przekładzie zatytułowane Duch filozofii średniowiecznej), wcześniej jednak, bo już w 1937 roku, zredagował je niemiecki franciszkanin, Philotheus Böhner, który nadał im bardziej wymowny tytuł: Die Geschichte der christlichen Philosophie von ihren Anfüngen bis Nikolaus von Cues, czyli Historia filozofii chrześcijańskiej! Ciekawym wyzwaniem byłoby porównanie obu tych wydań, ponieważ pomimo zasadniczego podobieństwa, pojawiają się tam dość ciekawe różnice. To właśnie w tej drugiej (a chronologicznie pierwszej) wersji pojawia się nie tylko definicja filozofii chrześcijańskiej (choć jednocześnie Gilson piórem Böhnera zastrzega, że rozumie to pojęcie wyłącznie w sensie historycznym), jak również listę istotnych jej cech.

Gilson tak zatem rozumie interesujące nas pojęcie: „Chrześcijańską nazywamy każdą filozofię wypracowaną przez wierzących chrześcijan, która rozdziela porządek wiedzy i wiary, a uzasadniając swoje tezy ar-

61 Ibidem. 
gumentami naturalnymi, widzi jednak w Objawieniu chrześcijańskim wielkiej wartości pomoc dla rozumu ludzkiego, pomoc w pewnej mierze nawet moralnie konieczną"62. Dyskusyjne jest oczywiście utożsamienie każdej ściśle rozumianej filozofii (czyli nie skażonej metodologicznie teologią) uprawianej przez chrześcijan i pod inspiracją tejże wiary za filozofię chrześcijańską - osobiście uważam to za zbyt szeroką definicję. Znacznie ciekawsze są jednak następujące po tym sformułowaniu dwie listy ${ }^{63}$. Pierwsza z nich wymienia „właściwości istotne filozofii chrześcijańskiej":

1) filozofia chrześcijańska zawiera tylko takie tezy, które mogą być udowodnione przy pomocy środków naturalnych;

2) filozofia chrześcijańska nie pozostaje nigdy w otwartej sprzeczności z jasno sformułowanymi prawdami wiary Kościoła chrześcijańskiego;

3) filozofia chrześcijańska musi się tworzyć pod świadomie percypowanym wpływem wiary chrześcijańskiej; wpływ ten jest natury psychologicznej, a nie systematycznej:

a) wiara strzeże przed błędem,

b) wiara wyznacza rozumowi określone cele poznawcze,

c) wiara wyznacza postawę poznawczą chrześcijańskiego filozofa,

d) wiara wyznacza sens filozofowania.

Mielibyśmy zatem trzy „istotne właściwości” omawianego nurtu, z jednej strony odróżniające filozofię chrześcijańską od teologii (właściwość pierwsza), a z drugiej od filozofii niechrześcijańskich (właściwość druga oraz cztery elementy tworzące właściwość trzecią). Obok nich Gilson i Böhner wymieniają trzy "cechy charakterystyczne” filozofii chrześcijańskiej:

1) każdą filozofię chrześcijańską cechuje tradycjonalizm, albowiem każdy system chrześcijański czuje się włączony w jeden wielki łańcuch, w którym jest on zawsze dalszym ciągiem i dalszym rozwinięciem czegoś wcześniejszego;

2) prawie każda filozofia chrześcijańska ma tendencję do przeprowadzania wyboru problemów;

3) prawie każda filozofia chrześcijańska ma silne tendencje do systematyzacji.

Pozostaje pytanie, jak postrzegać relację pomiędzy „istonymi właściwościami" a "cechami charakterystycznymi" filozofii chrześcijańskiej wydaje się jednak, że o ile pierwsze stanowiłyby warunki sine qua non uprawiania filozofii chrześcijańskiej i jej konieczne cechy, o tyle te drugie miały by charakter przygodny, w sposób historyczny i statystyczny blisko związane z rozmaitymi nurtami filozofii chrześcijańskiej. Tak więc

62 Philotheus Böhner, Étienne Gilson, Historia filozofii chrześcijańskiej, op. cit., s. 9.

63 Zob. ibidem, s. 9-13. 
Gilson i Böhner oferowaliby nam dość precyzyjny sprawdzian pozwalający odróżnić filozofię chrześcijańską zarówno od myśli chrześcijańskiej nie posiadającej walorów filozofii, jak i od niechrześcijańskich nurtów w filozofii.

Nie da się ukryć, że ta dwudziestowieczna (głównie frankofońska) debata miała wpływ nie tylko filozoficzny, ale także teologiczny, dosięgając najwyższych autorytetów Kościoła katolickiego. W tym świetle należałoby odczytywać encyklikę Fides et ratio, poświęconą zagadnieniu m.in. filozofii chrześcijańskiej, wydaną przez papieża Jana Pawła II w 1998 roku. Karol Wojtyła idzie śladem Etienne Gilsona, podając nie tylko własną definicję filozofii chrześcijańskiej, ale także listę jej cech ${ }^{64}$. Papież stwierdza, że choć „określenie to jest samo w sobie uzasadnione" - czyli filozofia chrześcijańska - to jednak „nie należy go jednak błędnie rozumieć: nie powinno ono sugerować, jakoby istniała jakaś oficjalna filozofia Kościoła, gdyż wiara jako taka nie jest filozofią. Ma ono raczej oznaczać chrześcijańską refleksję filozoficzną, spekulację filozoficzną powstałą w żywotnym związku z wiarą. Nie określa zatem wyłącznie filozofii wypracowanej przez filozofów chrześcijańskich, którzy w swoich poszukiwaniach nie chcieli zaprzeczać wierze. Mówiąc o filozofii chrześcijańskiej mamy na myśli wszystkie ważne kierunki myśli filozoficznej, które nie powstałyby bez bezpośredniego lub pośredniego wkładu wiary chrześcijańskiej". Definicja ta jest zatem dość bliska sformułowaniu, jakie podał wcześniej Gilson, choć można by rozważać, czy i na ile rozszerza ona koncepcję zaproponowaną przez francuskiego myśliciela. Z cała pewnością jednak lista cech filozofii chrześcijańskiej, jaką podał Jan Paweł II, nie jest tak precyzyjna, ani wyczerpująca, jak poprzednia.

Zawiera ona bowiem tylko cztery elementy. Po pierwsze, papież rozróżnia dwa aspekty filozofii chrześcijańskiej: aspekt subiektywny, polegający na „oczyszczeniu rozumu przez wiarę", jakiego może (i powinien) doświadczyć filozof proweniencji chrześcijańskiej, oraz aspekt obiektywny, dotyczący treści filozofii, która korzysta z tematów, zagadnień i prawd przekazanych przez objawienie chrześcijańskie. Obok tych dwóch elementów zostają wymienione dwie dalsze cechy charakterystyczne: specyficzny cel i zadanie filozofii chrześcijańskiej („,konieczność badania racjonalności pewnych prawd zawartych w Piśmie Świętym") oraz wierność własnym, filozoficznym i czysto racjonalnym metodom badań, właściwym dyskursowi filozoficznemu.

Z kolei pod wpływem tej encykliki - co zauważone zostaje w podtytule jego najważniejszej książki - pozostaje mniej znany warszawski filozof związany z Uniwersytetem Kardynała Stefana Wyszyńskiego, Kazi-

64 Zob. Jan Paweł II, Encyklika "Fides et ratio" do biskupów Kościoła katolickiego o relacjach między wiara a rozumem, Rzym (14 września) 1998, pkt. 76. 
mierz Szałata. Zaproponowana przez niego definicja jest ciekawa przede wszystkim dlatego, że nie ukrywa on trudności i niejasności zawartych w pojęciu „filozofia chrześcijańska”: „Samo określenie filozofia chrześcijańska jako filozofia uprawiana przez chrześcijan o tyle, o ile są ludźmi żyjącymi wiarą może się wydawać nieco niejasne i posiadać zabarwienie teologiczne. Ale wbrew pozorom w tym określeniu zawierają się pozostałe próby określenia filozofii chrześcijańskiej. Jeśli to jest filozofia tworzona przez kogoś, kto przyjął objawienie, to jest to filozofia uczciwie racjonalna i zarazem orientowana według problemów płynących z wiary. Jest to filozofia, która respektuje porządek rozumu i nadprzyrodzony porządek wiary. Jest to zarazem filozofia broniąca tej wiary przed atakami ze strony innych filozofii" 65 . Podobnie jak dwie poprzednie definicje afirmujące istnienie rzeczywistej filozofii chrześcijańskiej - a nie tylko jako fenomenu historycznego - i ta pozostaje dyskusyjna (np.: czy rzeczywiście istotną rolą filozofii jest obrona wiary chrześcijańskiej?). Znacznie bardziej interesujące z naszego punktu widzenia są warunki, które musi spełnić dany system, by móc być uznanym przez Szałatę za filozofię chrześcijańską. Warszawski myśliciel idzie tu drogą bliższą swemu promotorowi, wspomnianemu już Mieczysławowi Gogaczowi, nie odpowiadając na to pytanie wprost, lecz wymieniając "trzynaście sposobów posługiwania się pojęciem «filozofia chrześcijańska»":

1) filozofia chrześcijańska jako filozofia, która rozwija się w obszarze kultury europejskiej naznaczonej obecnością chrześcijaństwa;

2) filozofia chrześcijańska jako filozofia tworzona przez chrześcijan;

3) filozofia chrześcijańska jako filozofia uprawiana przez chrześcijan, o tyle, o ile są ludźmi żyjącymi wiarą;

4) filozofia chrześcijańska to po prostu filozofia prawdziwa;

5) filozofia chrześcijańska, jako filozofia negatywnie zweryfikowana przez wiarę;

6) filozofia chrześcijańska jako filozofia posługująca się porządkiem teologicznym w wyborze tematów;

7) filozofia chrześcijańska jako filozofia uznana przez Kościół;

8) filozofia chrześcijańska jako filozofia wykładana w szkołach chrześcijańskich, a ściślej mówiąc - w szkołach katolickich;

9) filozofia chrześcijańska jako filozofia scholastyczna;

10) filozofia chrześcijańska jako filozofia respektująca porządek poznania teologicznego;

11) filozofia chrześcijańska jako filozofia, która może być pomocą w życiu religijnym albo szerzej, jak pisze Gilson, „w dziele zbawienia ludzkości";

65 Kazimierz Szałata, Filozofia chrześcijańska. Na marginesie wielkiej debaty od encykliki "Aetarni Patris" do "Fides et ratio", Fundacja Polska Raoula Follereau, Warszawa 2004, s. 112-113. 
12) filozofia chrześcijańska jako filozofia klasyczna przyswojona przez chrześcijan;

13) filozofia chrześcijańska jako filozofia teistyczna ${ }^{66}$.

Wyraźnie widzimy, że pomiędzy tymi trzynastoma sformułowaniami znajdziemy zarówno te całkowicie błędne (np. pozycja siódma czy trzynasta), jak i nowatorskie i odkrywcze (np. sposób dwunasty). Niemniej, dzięki Szałacie widzimy, że samo opowiedzenie się za istnieniem prawdziwej filozofii chrześcijańskiej nie zamyka sprawy. Mamy bowiem do czynienia z tak wieloma i tak różnymi perspektywami, że przyznając się do uprawiania lub badania filozofii chrześcijańskiej, musimy dookreślić, co przez to pojęcie rozumiemy.

Ten problem zauważa inny współczesny polski - chyba dziś najbardziej uznany w temacie naszych wywodów - badacz filozofii chrześcijańskiej, związany z Uniwersytetem im. Adama Mickiewicza w Poznaniu Krzysztof Stachewicz. Z jego obszernego dorobku wybierzmy jedną $\mathrm{z}$ ostatnich prac, niejako zbierającą dotychczasowe wyniki prowadzonych badań, i przedstawmy te same dwa elementy, które staraliśmy się wyłuskać z myśli Gilsona, Jana Pawła II i Szałaty: definicję filozofii chrześcijańskiej oraz jej cechy.

Stachewicz w taki sposób ją opisuje: „Filozofią chrześcijańską sensu stricto możemy [...] nazwać taki typ filozofii, w której do głosu dochodzi afirmatywne podejście do dziedzictwa myślowego, intelektualnego chrześcijaństwa. Dzięki takiej postawie filozof może otwierać się w sensie pozytywnym oraz bezpośrednim na tradycję teologiczna, religijną i podążać w swym poszukiwaniu prawdy w kierunku wskazywanym przez metafizyczne światło niesione przez chrześcijaństwo (w kontekście odkrycia). Stanowi ono dla niego także normę negatywną każącą odrzucać rozwiązania radykalnie sprzeczne $\mathrm{z}$ duchem prawdy niesionej przez chrystianizm. Natomiast filozofią chrześcijańską sensu largo jest filozofia dopuszczająca inspiracje pośrednie, partycypująca w kulturze chrześcijańskiej, ustosunkowująca się pozytywnie lub negatywnie do myśli chrześcijańskiej. W tym sensie filozofią chrześcijańską byłaby prawie cała filozofia europejska, począwszy od przełomu starożytności i średniowiecza, poprzez czasy nowożytne aż do współczesności" ${ }^{\prime \prime 7}$. Poznański filozof dokonuje bardzo ciekawego - i chyba potrzebnego - rozróżnienia na filozofię chrześcijańską senstu stricto oraz sensu largo.

Odnosząc się do tego drugiego wymiaru, bardziej potocznego i mniej precyzyjnego, wymienia następnie dziesięć kryteriów, które są wskazywane - przez różnych badaczy, $\mathrm{w}$ różnym okresie, $\mathrm{z}$ różnych powodów - jako konstytutywne dla nurtu filozofii chrześcijańskiej.

66 Zob. ibidem, s. 103-111.

${ }^{67}$ Krzysztof Stachewicz, O filozofii chrześcijańskiej. Kilka uwag z perspektywy historycznej i futurologicznej, „Logos i ethos” 2(35)2013 s. 230-231. 
1) posługuje się pojęciami i ideami wypracowanymi i odkrytymi w tradycji chrześcijańskiej;

2) jest uprawiana przez chrześcijan;

3) jest uprawiana i nauczana w instytucjach kościelnych;

4) przyjmuje na zasadzie inspiracji tezy pochodzące z Objawienia i następnie je uzasadnia, wierzyć jest tu przekuwane na wiedzieć;

5) głosi tezy niesprzeczne z prawdami chrześcijaństwa (kryterium negatywne);

6) powstała i rozwija się w klimatach stworzonych przez chrześcijaństwo (cała filozofia europejska od starożytności chrześcijańskiej), niezależnie nawet od znajomości prawd chrześcijaństwa; wpływ nie zakłada wszak jako swego warunku jego świadomości;

7) posiada jakieś placet instytucji chrześcijańskich (jak tomizm w Aeterni Patris Leona XIII);

8) podejmuje tematy inspirowane przez dyskurs teologiczny lub stworzone przez dogmatykę religijną chrześcijaństwa;

9) otwiera na transcendencję, a przede wszystkim wskazuje na transcendencję jako kierunek zaangażowania człowieka, jego działania i spełniania się;

10) uznaje fundamentalne granice rozumu i otwiera świadomie filozoficzny system myślowy na poznanie z wiary (intellectus quaerens intellectum per fidem - Maine de Biran)" ${ }^{\prime 68}$.

Ta ciekawa próba zebrania i usystematyzowania różnych sposobów, według których starano się szufladkować filozofię chrześcijańska, wyraźnie pokazuje, jaki problem miano z tą ideą. Co ważniejsze, również dziś - co starałem się udowodnić w niniejszym artykule - ten dylemat (a $\mathrm{w}$ zasadzie trylemat, jeśli przyjmiemy powyższe trzy stanowiska jako paradygmatyczne) wciąż nie doczekał się wiążącego i powszechnie przyjmowanego rozwiązania. Mamy tak wiele prób zarówno zdyskredytowania koncepcji filozofii chrześcijańskiej, jak i prób jej afirmacji i obrony, a jednocześnie żadna z nich nie zdołała uzyskać dominującej pozycji...

\section{Podsumowanie dotychczasowych rozważań}

Rozpoczęliśmy od słów Zofii Zdybickiej i Edwarda Iwo Zielińskiego, zapisanych w Powszechnej Encyklopedii Filozofii, definiujących naszą ideę. Warto jednak przeczytać również dalszy ich fragment, bo nagle okaże się, że proste i chyba dość precyzyjnie określone pojęcie pozostaje - przynajmniej w części - „pobożnym życzeniem”. Zdybicka i Zieliński dodają bowiem natychmiast: „nadal dyskusyjne jest określenie [...], w jakim

68 Zob. tamże, s. 226-227. 
stopniu i w jaki sposób należy w filozofii uwzględniać dane objawienia chrześcijańskiego, aby można ją nazwać chrześcijańską filozofią" ${ }^{69}$. Co zatem możemy powiedzieć pewnego i precyzyjnego na temat pojęcia "filozofia chrześcijańska”, skoro nie potrafimy nawet określić wzajemnej relacji obu jego członów: „filozofia” i „chrześcijaństwo”? Czy spór pomiędzy negacjonistami i afirmatystami ma jakąkolwiek wartość, jeśli nie możemy zgodzić się co do tego, o co się spierają?

Tym, co jest szczególnie interesujące w rozważaniach Étienne Gilsona, to próba zdefiniowania idei filozofii chrześcijańskiej poprzez podanie zasadniczych jej cech. Zgadzając się z trzecim, afirmującym stanowiskiem, chciałbym w następnym numerze "Ruchu filozoficznego" zaproponować - krytycznie nawiązując do założeń przyjętych przez autora Ducha filozofii średniowiecznej - zaproponować listę pięciu cech konstytutywnych dla tego nurtu filozoficznego, bezpośrednio odnoszących się do etyki chrześcijańskiej jako jej istotnej części. Skoro bowiem mamy problem z ustaleniem definicji opisowej, może wystarczy nam ustalenie warunków brzegowych, pozwalających odróżnić filozofię i etykę chrześcijańską zarówno od filozofii niechrześcijańskich, jak i od innych, niefilozoficznych form aktywności chrześcijańskiej?

\section{Bibliografia}

Böhner Ph., Gilson É., Historia filozofii chrześcijańskiej: od Justyna do Mikołaja Kuzańczyka, tłum. Stanisław Stomma, PAX, Warszawa 1962.

Chudy W., Filozofia chrześcijańska - rozum i wiara, „Ethos” 3-4 (2007) 79-80, s. $45-66$.

Coreth E., Ehlen P., Haeffner G., Ricken F., Filozofia XX wieku, tłum. M.L. Kalinowski, Antyk, Kęty 2004.

Gilson É., Duch filozofii średniowiecznej, tłum. J. Rybałt, PAX, Warszawa 1958.

Gogacz M., Czym jest filozofia chrześcijańska, „Za i Przeciw” 14 (5 kwietnia) 1981, s. 6, 23.

Heidegger M., Fenomenologia $i$ teologia, tłum. J. Tischner, „Znak” 295-296 (1979), s. 119-134.

Heidegger M., Wprowadzenie do metafizyki, tłum. R. Marszałek, Wydawnictwo KR, Warszawa 2000.

Heller M., Sens życia i sens wszechświata. Studia z teologii wspótczesnej, Biblos, Tarnów 2002.

Jan Paweł II, Encyklika "Fides et ratio" do biskupów Kościoła katolickiego o relacjach między wiara a rozumem, Rzym (14 września) 1998.

Stachewicz K., O filozofii chrześcijańskiej. Kilka uwag z perspektywy historycznej i futurologicznej, „Logos i ethos” 2 (35) 2013 s. 219-234.

69 Zofia J. Zdybicka, Edward I. Zieliński, Chrześcijańska filozofia, art. cyt., s. 169. 
Swieżawski S., Święty Tomasz na nowo odczytany. Wykłady w Laskach, Znak, Kraków 1983.

Szałata K., Filozofia chrześcijańska. Na marginesie wielkiej debaty od encykliki "Aetarni Patris" do "Fides et ratio", Fundacja Polska Raoula Follereau, Warszawa 2004.

Tertulian, Preskrypcja przecizw heretykom, tłum. E. Stanula, w: tenże, Wybór pism, ATK, Warszawa 1970, s. 40-78.

Zdybicka Z.J., Zieliński E.I., Chrześcijańska filozofia, w: Powszechna Encyklopedia Filozofii, A. Maryniarczyk (red.), t. II, Polskie Towarzystwo Tomasza z Akwinu, Lublin 2001, s. 167-173.

\section{Streszczenie}

\section{O możliwości istnienia filozofii chrześcijańskiej}

\section{Słowa kluczowe}

Filozofia chrześcijańska; metafilozofia; Étienne Gilson; Wojciech Chudy; Krzysztof Stachewicz

Od blisko dwóch tysiąca lat trwa spór o możliwość istnienia filozofii specyficznie chrześcijańskiej i o sensowność posługiwania się tym pojęciem. Uważna analiza tej debaty pozwala wyróżnić trzy podstawowe nurty, paradygmaty myślenia o filozofii chrześcijańskiej: stanowisko odrzucające - z różnych powodów możliwość jej istnienia; grupę myślicieli uznających, że o filozofii chrześcijańskiej można mówić wyłącznie w kontekście chrześcijańskim, ale w żadnym wypadku metafilozoficznym; trzeci, który afirmuje istnienie zarówno historyczne, jak i merytoryczne istnienie specyficznie chrześcijańskiej filozofii. Niniejszy artykuł poświęcony jest zaprezentowaniu każdego z powyższych stanowisk, łącznie $\mathrm{z}$ ich argumentami, przede wszystkim na podstawie niektórych ich przedstawicieli - ze szczególnym uwzględnieniem współczesnych myślicieli polskich. 


\section{Summary}

\section{On the Possibility of Existence of a Christian Philosophy}

\section{Keywords}

Christian philosophy; metaphilosophy; Étienne Gilson; Wojciech Chudy; Krzysztof Stachewicz

For nearly twenty centuries lasts a debate on the possibility of the existence and meaningfulness of the Christian philosophy. The answers to these questions are clearly grouped into three paradigms: a) Christian philosophy does not exist (it is an "iron wood"); b) it exists only as a historical fact and can be examined only in this context; c) Christian philosophy is a valid, meaningful and distinct movement in European philosophy and its boundary conditions can be given. In this article an attempt will be made to describe each of these positions and to present main arguments of the selected representatives, so that we can see both the crucial points of the dispute as well as the possibility of resolving them. 